\title{
Inhibitory Effects of Methanol Stem Bark Extracts of Sterculia Setigera and Ficus Platyphylla on Hemoglobin Glycosylation and $\alpha$-amylase
}

\author{
Ukwuani-Kwaja A. N., Nwaogu J., "Abba A., Yahaya M. \\ Department of Biochemistry, Faculty of Life Sciences, Kebbi State University of Science and Technology, Aliero, Kebbi State, \\ Nigeria
}

Received June 29, 2021; Revised August 11, 2021; Accepted August 28, 2021

\section{Cite This Paper in the following Citation Styles}

(a): [1] Ukwuani-Kwaja A. N., Nwaogu J., Abba A., and Yahaya M. , "Inhibitory Effects of Methanol Stem Bark Extracts of Sterculia Setigera and Ficus Platyphylla on Hemoglobin Glycosylation and $\alpha$-amylase," Advances in Diabetes and Metabolism, Vol. 9, No. 2, pp. 13 - 18, 2021. DOI: 10.13189/adm.2021.090201.

(b): Ukwuani-Kwaja A. N., Nwaogu J., Abba A., and Yahaya M. (2021). Inhibitory Effects of Methanol Stem Bark Extracts of Sterculia Setigera and Ficus Platyphylla on Hemoglobin Glycosylation and $\alpha$-amylase. Advances in Diabetes and Metabolism, 9(2), 13 - 18. DOI: 10.13189/adm.2021.090201.

Copyright $@ 2021$ by authors, all rights reserved. Authors agree that this article remains permanently open access under the terms of the Creative Commons Attribution License 4.0 International License

\begin{abstract}
Diabetes Mellitus is a chronic metabolic disorder characterized by hyperglycemia due to abnormal insulin secretion, action or both. The synthetic available anti-diabetic drugs exhibited various adverse effects such as diarrhea, hypoglycemia. In recent years, scientists have turned their attention towards the medicinal plants which bear the rich source of metabolites which offer specific therapeutic function in the human body without any adverse effect. Sterculia setigera and Ficus platyphylla are medicinal plants that are used to treat various diseases and including diabetes traditionally. The present study is aimed at investigating the antidiabetic activity of the $S$. setigera and $F$. platyphylla methanol stem bark extracts. Phytochemical screening was determined using the standard method. In vitro studies were carried out using $\alpha$ amylase and glycosylated hemoglobin inhibitory assay. The results of phytochemical constituents detected were flavonoids, Tannins, Steroids, Saponins, cardiac glycosides, Terpenoids, and Phenols. Inhibitory effects of both plant extracts were dose dependent against haemoglobin glycosylation and $\alpha$-amylase. At highest concentration $(25 \mathrm{mg} / \mathrm{ml})$, highest inhibitions were recorded in S. setigera $(70.30 \%)$ and $F$. platyphylla (70.00\%) which was comparable to Metformin (57. 2\%). $\mathrm{IC}_{50}$ of Sterculia setigera $(3.18 \mathrm{mg} / \mathrm{ml})$ and Ficus platyphylla $(5.97 \mathrm{mg} / \mathrm{ml})$ were lower than metformin $(8.84$ $\mathrm{mg} / \mathrm{ml}$ ) against hemoglobin glycosylation. At
\end{abstract}

concentration of $(1.0 \mathrm{mg} / \mathrm{ml})$ S. setigera $(72.21 \%)$ and $F$. platyphylla the $(70.41 \%)$ showed the highest inhibitory effect which was not significantly different $(p<0.05)$ compared to Voglibose (83.47\%). In the present study, the $\mathrm{IC}_{50}$ of both extracts were higher $(0.64$ and $0.69 \mathrm{mg} / \mathrm{ml})$ and not significantly comparable to the Voglibose $(0.26 \mathrm{mg} / \mathrm{ml})$. In conclusion, this study suggests that Sterculia setigera and Ficus platyphylla methanol stem bark extract possess hypoglycaemic potentials. This justifies their ethnomedicinal use for the treatment of diabetes.

Keywords Ficus Platyphylla, Sterculia Setigera, Antidiabetic, $\alpha$-amylase, Haemoglobin

\section{Introduction}

Diabetes mellitus could also be a set of prolonged metabolic disorders characterized by hyperglycemia as a result of defects in insulin secretion, action, or both [1]. The increasing incidence of diabetes mellitus worldwide among all age groups irrespective of sex, race, socioeconomic status, or ethnicity, constitutes a global public health burden [1-3]. Clinically, we have two major types of diabetes mellitus (DM), type1 DM represents 
insulin dependent diabetes mellitus as a result of acute or chronic insulin deficiency in plasma and accounts for 5$10 \%$ of all cases of diabetes mellitus and is caused by the autoimmune destruction of pancreatic $\beta$-cells which results in insulin deficiency [6]. On the opposite hand, Type 2 DM (T2DM) is one among the foremost common metabolic disorders worldwide and its development is primarily caused by a mixture of two main factors: defective insulin secretion by pancreatic $\beta$-cells and therefore the inability of insulin sensitive tissues to reply to insulin [24].

Globally, about 415 million individuals were affected with diabetes in 2015 and this has been projected to extend to 629 million by 2045 [5]. Previous report revealed that prevalence of DM in Nigeria has increased from $2.2 \%$ in 1997 to $5.0 \%$ by 2013 [4]. The high costs and adverse effects of insulin and therefore the available oral hypoglycaemic agents have necessitated increased investigations on medicinal plants used ethnomedically for the management of diabetes [8-9]. According to the WHO, over $80 \%$ of the world's population depend upon traditional sorts of medicine, largely plant based to satisfy primary health care needs [18]. Medicinal plants and their bioactive constituents are used for the treatment of diabetes mellitus throughout the world [19]. The present study was designed to investigate the antidiabetic activities of Sterculia setigera and Ficus platyphylla methanol stem bark extract with a view to justifying its antidiabetic folkloric claims

\section{Materials and Methods}

\subsection{Materials}

\subsubsection{Chemical and Reagents}

All chemicals used were of analytical grade

\subsubsection{Equipments/ Instrumentation}

Spectrophotometer, rotary evaporator, incubator, test tube, beaker, cuvette, test tube rack, syringe

\subsubsection{Plants Collection and Identification}

Fresh stem bark of Sterculia Setigera and Ficus Platyphylla were collected in November, 2020 at local farmlands Zuru Local Government Area, Kebbi State. It was identified and authenticated by a Taxonomist at the Botany Unit department of Plant Science and Biotechnology, Kebbi State University of Science and Technology, Aliero. Voucher specimens (KSUSTA/PSB/H/VOUCHER NO: 29A and KSUSTA/PSB/H/VOUCHER NO: 83B) have been deposited in the Herbarium of the same institution for further reference.

\subsubsection{Anti-diabetic Conventional Drug}

Voglibose (Macrolabs, INDIA) and Metformin (Sanofi
Aventis, INDIA) were purchased in December, 2020 from Hamdala Pharmacy Birnin Kebbi, Kebbi State.

\subsection{Methods}

\subsubsection{Preparation of Plant Material}

The stem bark of both plants was shade dried at room temperature for seven days to liberate moisture content and reduce to a constant weight. Dried stem bark of both plants were powdered individually in a clean mortar and pounded with a pestle. The powdered material was sieved and stored in a sterile, tight container until needed. Two hundred fifty grams (250g) of each powdered plant material was weighed and subjected to cold maceration using 1250L of methanol and was allowed to stand for 75 hours with occasional turning and shaking. The mixture was filtered afterward with a clean white Muslim cloth. The filtrate obtained was evaporated to dryness using a rotary evaporator at $45^{\circ} \mathrm{C}$ [10].

\subsection{Qualitative Phytochemical Screening}

\subsubsection{Test for Alkaloids (Dragendroff's Test)}

About $0.5 \mathrm{~g}$ of each plant extracts was stirred with $5 \mathrm{ml}$ of $1 \%$ dilute hydrochloric acid on a steam bath; $1 \mathrm{ml}$ of the filtrate was treated with a few drops of reagent, and a second $1 \mathrm{ml}$ of extract was treated with Dragendroff's reagent. Presence of turbidity or precipitation is evidence for the presence of alkaloids [31].

\subsubsection{Test for Flavonoid (Alkaline Reagent Test)}

Few drops of Sodium hydroxide were added to $5 \mathrm{ml}$ of each extracts, a yellow coloration.

\subsubsection{Test for Tannins (Ferric Chloride Test)}

About $0.5 \mathrm{ml}$ of each plant extract was stirred with $5 \mathrm{ml}$ of distilled water and then filtered and 23 drops of ferric chloride reagent was added to the filtrate. Black or bluegreen precipitate was taken as evidence for the presence of tannins [31].

\subsubsection{Test for Saponins (Frothing Test)}

Exactly $5 \mathrm{ml}$ of each plant extracts in a test tube, $5 \mathrm{ml}$ of distilled water was added to each test tube and shaken strongly. The formation of froth that lasted for several minutes is an indication of the presence of saponins (Harbone, 1973).

\subsubsection{Test for Cardiac Glycosides (Keller- Mililani’s Test)}

$2 \mathrm{ml}$ of each plant extract was added to $2 \mathrm{ml}$ of $3.5 \%$ Ferric chloride solution in two different test tubes and was allowed to stand for a minute. About $1 \mathrm{ml}$ of concentrated $\mathrm{H}_{2} \mathrm{SO}_{4}$ was carefully poured right down to the wall of the tube to make a lower layer. A reddish-brown ring at the interface indicated the presence of cardiac glycosides [28]. 


\subsubsection{Test for Terpenoids (Salkowski Test)}

$2.5 \mathrm{ml}$ of both plant extract was mixed with $1 \mathrm{ml}$ of chloroform and $1.5 \mathrm{ml}$ concentrated $\mathrm{H} 2 \mathrm{SO} 4$ was carefully added to make a layer during a different tube. A reddishbrown coloration at the interface indicates a positive result for the presence of terpenoids [31].

\subsubsection{Test for Phenolic Compound}

$2 \mathrm{ml}$ of methanol stem bark extract of Sterculia setigera and Ficus platyphylla was mixed with $2 \mathrm{ml}$ of ferric chloride solution and the mixture was shaken individually. Dark green colour indicates the presence of the phenolic compound of phenols [12].

\subsubsection{Test for Carbohydrates (Molisch’s Test)}

$20 \mathrm{mg}$ of both plant extracts was dissolved in $5 \mathrm{ml}$ distilled water differently and filtered. The filtrate was treated with 2 drops of alcoholic $\alpha$-naphthol solution during a tube. The formation of the violet ring at the junction indicates the presence of Carbohydrates [31].

\subsection{In vitro Antidiabetic Assay}

\subsubsection{Non-enzymatic Glycosylation of Haemoglobin Inhibitory Assay}

$1 \mathrm{ml}$ of Glucose (2\%), haemoglobin $(0.06 \%)$ and Gentamicin $(0.02 \%)$ was prepared in a phosphate buffer $0.01 \mathrm{M}$ at $\mathrm{pH} 7.4$ each and mixed together. Then methanol extracts of both plants were weighed and dissolved in distilled water to obtain various concentrations of $525 \mathrm{mg} / \mathrm{ml}$ of (SSME and FPME). Then $1 \mathrm{ml}$ of each concentration of plant extracts was added to the above mixture. The mixture was incubated in darkness at room temperature for 72 hrs. The inhibitory effect of plant extracts on glycosylation of haemoglobin was measured using spectrophotometric at 443nm [13]. Metformin was used as a standard drug for assay and \% inhibition was calculated using the formula:

$$
\text { Percentage Inhibition }=(\text { Abs Sample }- \text { Abs Control }) /
$$

(Abs Sample) $\times 100 / 1$

\{Where Abs Control = absorbance of the control reaction (containing all the reagents with the exception of the test sample) and Abs sample is the absorbance of the test sample and the IC50 values (inhibitory concentration which will produce $50 \%$ inhibition of the enzyme activity) of the plant extracts were (inhibitory concentration which will produce $50 \%$ inhibition of the enzyme activity) of the plant extracts were determined using (ic50.tk/index.html)\}.

\subsection{2. $\alpha$-Amylase Inhibitory Assay}

In the $\alpha$-amylase inhibitory method, the enzyme solution was prepared by dissolving $50 \mathrm{mg}$ of $\alpha \neg$ amylase in $100 \mathrm{ml}$ of $20 \mathrm{mM}$ phosphate buffer (6.9) and obtaining concentration of $0.5 \mathrm{mg} / \mathrm{ml}$. $1 \mathrm{ml}$ of various concentrations
(0.2, 0.4, 0.6, 0.8 and $1 \mathrm{mg} / \mathrm{ml})$ of both plant extracts was mixed with $1 \mathrm{ml}$ of enzyme solutions and incubated at $25^{\circ} \mathrm{C}$ for $10 \mathrm{~min}$. After incubation, $1 \mathrm{ml}$ of starch $(1 \%)$ solution was added to the mixture and further incubated at $25^{\circ} \mathrm{C}$ for $10 \mathrm{~min}$. The reaction was stopped by adding $2 \mathrm{ml}$ of dinitrosalicylic acid (DNS, color reagent), heating the reaction mixture in a boiling water bath for five ( $5 \mathrm{~min})$. After cooling, the absorbance of the mixture was measured spectrometrically at $540 \mathrm{~nm}$ [23].

The inhibition percentage was calculated using the given formula,

$$
\text { Percentage Inhibition }=\frac{\text { Abs Control-Abs Sample }}{\text { Abs Control }} \times \frac{100}{1}
$$

\{Where Abs control is the absorbance of the control reaction (containing all reagents except the test sample) and Abs sample is the absorbance of the test sample and The $\mathrm{IC}_{50}$ values (inhibitory concentration which will produce $50 \%$ inhibition of the enzyme activity) of the plant extracts were determined using (ic50.tk/index.html)\}.

\subsection{Statistical Analysis}

The data were expressed as mean \pm S.E.M. The significance of the difference of the mean value for both standard drug and that of plant extract was analyzed using one-way ANOVA followed by Duncan multiple comparison test. $\mathrm{p}<0.05$ was as considered to be significantly different.

\section{Results}

\subsection{Results of Phytochemical Screening}

The qualitative phytochemical screening of Sterculia setigera and Ficus platyphylla methanol stem bark extract is presented in (Table 1). The results for the phytochemical screening of Sterculia setigera revealed the presence of Alkaloids, Flavonoids, Tannins, Steroids, Saponins, Carbohydrates, Cardiac glycoside, Phenols and Terpenoids.

Table 1. Qualitative Phytochemical Constituents of Sterculia setigera and Ficus platyphylla Methanol Stem Bark Extract.

\begin{tabular}{ccc}
\hline PHYTOCHEMICALS & S. SETIGERA & F. PLATYPHYLLA \\
\hline ALKALOIDS & - & - \\
FLAVONOIDS & + & + \\
TANNINS & + & - \\
SAPONIN & + & + \\
CARBOHYDRATES & + & + \\
CARDIAC GLYCOSIDE & + & + \\
PHENOLS & + & + \\
TERPENOIDS & + & + \\
\hline
\end{tabular}

KEYS: + = Present, - = Not Detected 


\subsection{Effect of $F$. platyphylla and S. setigera on Haemoglobin Glycosylation}

There was a dose-dependent increase in percentage inhibitory effect against hemoglobin glycosylation over the period of $72 \mathrm{hrs}$, as the concentration of plant extracts increases (Table 2). This suggests that the plant extracts decrease the formation of the glucose-haemoglobin complex and thus the amount of free haemoglobin increases. At highest concentration $(25 \mathrm{mg} / \mathrm{ml})$ highest inhibitions were recorded in S. setigera $(70.30 \%)$ and F. platyphylla $(70.00 \%)$ which was comparable to Metformin (57. 2\%). $\quad \mathrm{IC}_{50}$ of Sterculia setigera $(3.18 \mathrm{mg} / \mathrm{ml})$ and Ficus platyphylla $(5.97 \mathrm{mg} / \mathrm{ml})$ were lower than metformin $(8.84 \mathrm{mg} / \mathrm{ml})$ indicating that the plant extract is more potent than standard drug against hemoglobin glycosylation.

Table 2. Heamoglobin Glycosylation Inhibitory Effect of F. platyphylla and S. setigera Methanol Stem Bark Extracts

\begin{tabular}{ccccc}
\hline Period & $\begin{array}{c}\text { Conc } \\
\mathrm{mg} / \mathrm{ml}\end{array}$ & Metformin & S. setigera & $\begin{array}{c}\text { F. } \\
\text { platyphylla }\end{array}$ \\
\hline \multirow{6}{*}{$24 \mathrm{hrs}$} & 5 & $2.37 \pm 0.01$ & $6.00 \pm 0.02$ & $20.00 \pm 0.02$ \\
& 10 & $8.13 \pm 0.01$ & $30.80 \pm 0.03$ & $27.70 \pm 0.03$ \\
& 15 & $15.15 \pm 0.01$ & $38.67 \pm 0.01$ & $33.30 \pm 0.05$ \\
& 20 & $25.50 \pm 0.01$ & $46.25 \pm 0.15$ & $34.90 \pm 0.05$ \\
& 25 & $33.60 \pm 0.02$ & $48.20 \pm 0.02$ & $38.80 \pm 0.06$ \\
& 5 & $13.60 \pm 0.01$ & $48.90 \pm 0.01$ & $43.70 \pm 0.05$ \\
$48 \mathrm{hrs}$ & 10 & $31.30 \pm 0.01$ & $61.10 \pm 0.09$ & $50.10 \pm 0.02$ \\
& 15 & $34.06 \pm 0.01$ & $62.70 \pm 0.05$ & $60.30 \pm 0.03$ \\
& 20 & $34.60 \pm 0.04$ & $63.50 \pm 0.03$ & $62.50 \pm 0.02$ \\
& 25 & $34.80 \pm 0.01$ & $65.00 \pm 0.17$ & $65.40 \pm 0.01$ \\
& 5 & $17.71 \pm 0.01$ & $55.49 \pm 0.05$ & $56.51 \pm 0.03$ \\
& 10 & $36.33 \pm 0.01$ & $68.10 \pm 0.02$ & $63.03 \pm 0.01$ \\
$72 \mathrm{hrs}$ & 15 & $44.53 \pm 0.02$ & $68.5 \pm 0.03$ & $66.27 \pm 0.03$ \\
& 20 & $55.03 \pm 0.20$ & $69.40 \pm 0.03$ & $68.76 \pm 0.01$ \\
& 25 & $57.52 \pm 0.04$ & $70.30 \pm 0.04$ & $70.00 \pm 0.03$ \\
& IC 50 & 8.84 & 3.18 & 5.97 \\
\hline
\end{tabular}

Values are expressed as mean \pm SEM of $n=3$

\section{3. a-Amylase Inhibitory Effects of F. platyphylla and S. setigera Methanol Stem Bark Extracts}

A dose-dependent increase in $\alpha$-Amylase inhibition was exhibited by Sterculia setigera and Ficus platyphylla as their concentration increases (Table 3). At concentration of $(1.0 \mathrm{mg} / \mathrm{ml})$ S.setigera $(72.21 \%)$ and F. platyphylla (70.41\%) showed the highest inhibitory effect which was not significantly different $(\mathrm{p}<0.05)$ compared to Voglibose (83.47\%). In the present study, the IC S0 $_{50}$ of both extracts were higher $(0.64$ and $0.69 \mathrm{mg} / \mathrm{ml})$ and comparable to the Voglibose $(0.26 \mathrm{mg} / \mathrm{ml})$ suggesting that the voglibose is more potent than both extracts.
Table 3. $\alpha$-amylase Inhibitory Effect of F. platyphylla and S. setigera Methanol Stem Bark Extract

\begin{tabular}{cccc}
\hline Conc.mg/ml & \multicolumn{3}{c}{ \% inhibition (mean \pm SEM) } \\
\hline & S. setigera & F. platyphylla & Voglibose \\
\hline 0.2 & $14.07 \pm 0.02^{\mathrm{d}}$ & $16.52 \pm 0.01^{\mathrm{d}}$ & $17.48 \pm 0.00^{\mathrm{c}}$ \\
0.4 & $19.03 \pm 0.03^{\mathrm{c}}$ & $17.96 \pm 0.01^{\mathrm{d}}$ & $48.38 \pm 0.01^{\mathrm{c}}$ \\
0.6 & $44.01 \pm 0.02^{\mathrm{c}}$ & $33.00 \pm 0.02^{\mathrm{c}}$ & $60.59 \pm 0.05^{\mathrm{b}}$ \\
0.8 & $58.20 \pm 0.03^{\mathrm{b}}$ & $58.20 \pm 0.04^{\mathrm{b}}$ & $70.65 \pm 0.04^{\mathrm{b}}$ \\
1.0 & $72.21 \pm 0.02^{\mathrm{a}}$ & $70.41 \pm 0.03^{\mathrm{a}}$ & $83.47 \pm 0.00^{\mathrm{a}}$ \\
IC $50 \mathrm{mg} / \mathrm{ml}$ & 0.64 & 0.69 & 0.26 \\
\hline
\end{tabular}

Values are mean \pm SEM of triplicate determinations. Values having different superscripts are significantly different $(\mathrm{p}<0.05)$

\subsection{Discussion}

Phytochemicals obtained from medicinal plants offer a promising alternative for the development of new therapeutic agents against diabetes mellitus [14]. The use of medicinal plants has a long folkloric history for the treatment of diabetes mellitus as well as oxidative stress related conditions [33-34]. Secondary metabolites such as Flavonoids, Steroids, Triterpenoids, Saponins, Alkaloids, and Phenolic have been reported to possess antidiabetic activities [27, 30]. This activity might be achieved by stimulating insulin release from pancreatic ß-cells, inhibiting glucose absorption in the gut, inhibiting carbohydrates digesting enzymes, stimulating glycogenesis in the liver and/or increasing glucose utilization by the body [16]. The hypoglycemic effects observed in the present study, of both plant extracts may be due to the presence of such phyto-constituents in the plant extracts.

In vitro non-enzymatic glycosylation of hemoglobin method is one of the important assays to evaluate the control of diabetes [22]. The hemoglobin attached to RBCs has an affinity to bind to glucose. The greater the glucose level in the blood the higher the amount of glucose hemoglobin complex will be formed [7, 22]. Consequently, the presence of a higher concentration of glycosylated hemoglobin is a sure guide to the higher concentration of glucose in the blood. Normal percentage of Glycated hemoglobin should not exceed $12 \%$ in the human blood [32]. The current study revealed that both plant extracts exhibited good inhibitory activities on glucose-hemoglobin complex formation by preventing such complexes (that is glucose binds to the surface of proteins). This is in corroboration with the previously reported research on different plant extracts $[11,15,17$, $21,26,32]$. 
$\alpha$-amylase enzyme is one of the enzymes responsible for the hydrolysis of aoriented bond polysaccharides and oligosaccharides such as starch, glycogen, and other macromolecules of abond linked monosaccharides to disaccharides and finally, to glucose [29]. It is well known that the reduction of postprandial hyperglycemia can be achieved by inhibiting intestinal $\alpha$-glucosidase and pancreatic aamylase activity via delayed carbohydrate digestion [20]. It is reported that when $\alpha$ amylase, glucose, plant extract are taken together as a solution, the plant extract causes the inhibition of the enzyme activity [35]. In the present study, the potent inhibitory activities of Sterculia setigera and Ficus platyphylla methanol stem bark extracts observed suggest that both plants possess the antidiabetic effects. In the present study, the potent inhibitory effects of Sterculia setigera and Ficus platyphylla methanol stem bark extracts observed suggest that both plants possess the antidiabetic effects. These inhibitory potentials may be ascribed to the presence of phytochemical constituents such as flavonoids, tannins, and Saponins which have also been reported previously to inhibit aamylase activity [25].

\section{Conclusion}

In conclusion, S. setigera and F. platyphylla stem bark extract produced inhibitory effects against haemoglobin glycosylation and $\alpha$-amylase validating hypoglycemic potentials of both extracts. This supports ethnopharmacological use of these plants in the management of diabetes.

\section{REFERENCES}

[1] International Diabetes Federation. IDF Diabetes Atlas. 7th ed. Brussels, Belgium; Available from: http://www.idf.org/ diabetes atlas 2015, Last accessed on 2016 Dec 13.

[2] World Health Organisation. Global Report on Diabetes. World Health Organization, Geneva, 2016, pp. 1-88

[3] Okoduwa, S. I., Umar, I. A., Ibrahim, S., Bello, F., and Ndidi, U. S. Socio-economic status of patients with type 2 diabetes and hypertension attending the Ahmadu Bello University Teaching Hospital, Zaria, North-West Nigeria. Global journal of health science, 7(1) pp. 280-287, 2014. https://doi.org/10.5539/gjhs.v7n1p280

[4] International Diabetes Federation. Diabetes Atlas. 6th Edition. International Diabetes Federation, 2013. Available at: http://www.idf.org/diabetesatlas.

[5] International Diabetes Federation (IDF). IDF Diabetes Atlas. 8th Edition, International Diabetes Federation, Brussels. 2017. http://www.diabetesatlas.org/resources/2017-atlas.html

[6] Ohiagu, F., Chikezie, P., and Chikezie, C. Pathophysiology of diabetes mellitus complications: Metabolic events and control. Biomedical Research and Therapy, 8(3), 42434257, 2021. https://doi.org/10.15419/bmrat.v8i3.663

[7] Daksha, G., Chandrashekher, K.S. and Pal, G. In vitro antidiabetic activity of Pentacyclic tritrprnoida and fatty acid esters from Bauhinia purpurea. International Journal of Pharmacology and Pharmaceutical Technology, 2 (1). pp. 25-28. 2013 ISSN 2277-3436

[8] Adebajo, A. C., Ayoola, M. D., Odediran, S. A., Aladesanmi, A. J., Schmidt, T. J., and Verspohl, E. J. Evaluation of ethnomedical claim III: anti-hyperglycemic activities of Gongronema latifolium root and stem. Journal of diabetes, 5(3), 336-343, 2013. https://doi.org/10.1111/1753-0407.12019

[9] Ayoola M.D, Akinwunmi, K.F. and Agboola, O.B. Antidiabetic and Antioxidant Activities of Entandropharagmacylindricum and Triclisiasubcordata. Nigerian Journal of Natural Products and Medicine 21:24312017.

[10] Aliyu, B.S., and Sani, H. Dambatta. In-vitro antibacterial activity of Anogeissus leiocarpus (stem bark) extracts against Escherichia coli and Staphylococcus aureus. Bayero Journal of Pure and Applied Sciences, 4(2): 56 59, 2011 DOI - 10.4314/bajopas.v4i2.11

[11] Hosseini, M., Asgary, S., and Najafi, S. Inhibitory potential of pure isoflavonoids, red clover, and alfalfa extracts on hemoglobin glycosylation. Advanced research yields in atherosclerosis, 11(2), 133-138, 2015. ISSN:1735-3955PMID: 26405442; PMCID: PMC4568198.

[12] Harborne, J. B. Phytochemical methods: A guide to modern techniques of plant analysis. Chapman and Hall Ltd, London.; Pp. 279, 1973.

[13] Abirami, N., Natarajan, B. and Sagadevan, E. Phytochemical investigation and in vitro evaluation of hypoglycemic potential of Grewiahirsuta. Int J Pharm Bio Sci, 5: 76- 83, 2014.http://dx.doi.org/10.1016/j.fshw.2014.02.001

[14] Ajiboye, H., Akinyemi A, Saliu, J. and Schwarzenbolz, U. Hypoglycaemic and antidiabetic activity of flavonoids: boswellic acid, ellagic acid, quercetin, rutin on streptozotocin-nicotinamide induced type 2 diabetic rats, Int. J. Pharm.Pharm. Sci. 4 (2) 251-256, 2016. https://doi.org/10.1002/fsn3.749

[15] James, S.A., Auta, R. And Goje, D.J. In Vitro Study on Inhibition of Glycosylation of Methanolic Leaf Extract of Hibiscus cannabinus. Science World Journal Vol 6 No 32011. ISSN 1597-6343

[16] Kifle, Z. D., and Enyew, E. F. Evaluation of In Vivo Antidiabetic, In Vitro $\alpha$-Amylase Inhibitory, and In Vitro Antioxidant Activity of Leaves Crude Extract and Solvent Fractions of Bersama abyssinica Fresen (Melianthaceae). Journal of Experimental Pharmacology, 25, 2515690X20935827, 2020 https://doi.org/10.1177/2515690X20935827

[17] Mangesh, B., Somnath, B., Dheeraj, R., Ganesh, W. and Sachin, T. Studies on In-Vitro Antiglycation Potential of Some Indigenous Antidiabetic Plants. Global Journal of Pharmaceutical Scienceces 3(5): 555-624, 2017. DOI: 10.19080/GJPPS.2017.03.555624 
[18] Mazid, M, Taqi, A.K., and Firoz M. Medicinal plants of Rural India: A review of Use by Indian Folks. Indo Global Journal of Pharmaceutical Sciences, 2(3); 286 - 304, 2012 ISSN 2249- 1023

[19] Mohan, V.R., Mary, S., Kala, J. and Tresina, P.S. Antioxidant, Antihyperlipidaemic And Antidiabetic Activi.ty of Eugenia Singampattiana Bedd Leaves In Alloxan Induced Diabetic Rats. International Journal of Pharmacy and Pharmaceutical Sciences, Vol 4 (3) 412416, 2011. ISSN- 0975-1491. https://doi.org/10.4103/0976-0105.103831

[20] Elloumi, D, Aloulou, A., Hamden, K., Ali, M.B., Hargafi, K., Jaouadi, B., Ayadi, F., Elfeki, A. and Ammar, E. Hypoglycemic and antilipidemic properties of of kombucha tea in alloxan-induced diabetic rats. BMC Complementary and Alternative Medicine 16 (12)63, 2012. ISSN - 1472-6882 doi: 10.1186/1472-6882-12-63.

[21] Omonije, O.O., Saidu, N.A. and Muhammad, L.H. Antidiabetic activities of Chromolaena odorata methanol root extract and its attenuation effect on diabetic induced hepatorenal impairments in rats. Clinical Phytoscience 5(1)23, 2019. ISSN 2199-1197. https://doi.org/10.1186/s40816-019-0115-1

[22] Radhika, S., Senthil, K.R., Sindhu, S., Sagadevan, E. and Arumugam, P. Phytochemical investigation and evaluation of antihyperglycemic potential of Premna corymbosa. International Journal of Pharmaceutical Sciences and Research Vol. 4(10) 352-356. 2013. ISSN 3925-3931.

[23] Rammohan, S., Zaini, A.M. and Amirin, S. In vitro $\alpha$ glucosidase and $\alpha$-amylase enzyme inhibitory effects of Andrographis paniculata extract and andrographolide. Acta Biochimica Polonica; 55(2):391-398, 2008 on-line at: www.actabp.pl

[24] Roden, M. and Shulman, G.I. The integrative biology of type 2 diabetes. Nature, 576, 51-60, 2019. ISSN 14764687 https://doi.org/10.1038/s41586-019-1797-8

[25] Sarma, A.D., Mallick, A.R. and Ghosh, A.K. Free Radicals and Their Role in Different Clinical Conditions: An Overview, International Journal of Pharma Sciences and Research, Vol. 1, No. 3, pp. 185-192, 2010

[26] Selvi. R. and Yogananth, N. In vitro evaluation of antidiabetic potential of leaf and stem extracts of Solanum xanthocarpum and Solanum nigrum. Int. J. Adv. Res. Biol. Sci. 3(12):191-195 ISSN: 2348-8069, 2016. DOI: http://dx.doi.org/10.22192/ijarbs

[27] Sharma, B., Salunke, R., Balomajumder, C., Daniel, S. and Roy, P. Antidiabetic potential of alkaloid rich fraction from Capparis decidua on diabetic mice. Journal of Ethnopharmacol. 127(2):457-462, 2010. doi:10.101 6/j.jep.2009.10.013

[28] Sofowora, A. Medicinal plants and traditional medicine in Africa. $2^{\text {nd }}$ Edition. Spectrum Books Limited, Sunshine House, Ibadan, Nigeria, 289, 1993.

[29] Suganya, G., Sampath, K.P., Dheeba, B. and Sivakumar, R. In vitro antidiabetic, antioxidant and ýanti-inflammatory activity of Clitoriaternatea. L. Int J Pharm Pharm Sci, 6:342-7, 2017.

[30] Sunmonu, T.O. and Afolayan, A.J. (2013). Evaluation of antidiabetic activity and associated toxicity of artemisia afra aqueous extract in wistar rats. Evid Based Complement Alternat Med. 1-8, 2013. doi:10.1155/ 2013/929074

[31] Trease G. and Evans M. Text Book of Pharmacognosy 13th Edition Bailiere Tindall. London, Toronto: Tokyo. Pgs; 200-201, 1989.

[32] Al-Ahmed, A. and Khalil, E.H. Antidiabetic Activity of Terfeziac laveryi; An in vitro and in vivo Study. Biomedical and Pharmacology Journal. Vol. 12(2), p. 603-608, 2019. http://dx.doi.org/10.13005/bpj/1680

[33] Saeed, N., Khan, M. R., \& Shabbir, M. Antioxidant activity, total phenolic and total flavonoid contents of whole plant extracts Torilis leptophylla L. BMC complementary and alternative medicine, 12, 221, 2012. https://doi.org/10.1186/1472-6882-12-221

[34] Dastjerdi, Z.M., Namjoyan, F. and Azemi, M.E. Alpha amylase inhibition activity of some plant extract of Teucrium species. European Journal of Biological Sciences 7 (1): 26-31, 2015 DOI: 10.5829/idosi.ejbs.2015.7.01.91127.

[35] Suhashini, R., Sindhu, S., and Sagadevan, E. Invitro evaluation of antidiabetic potential and phytochemical profile of Psoralea corylifolia Seeds. International Journal of Pharmacognosy and Phytochemical Research, 2014, $6(2)$;

414-419. 